\title{
A peste em Atenas: lições para os tempos de pandemia de Covid-19
}

\author{
The Plague of Athens: lessons for the time of the Covid-19 pandemic
}

\section{José Lourenço Pereira da Silva*}

Resumo: $\mathrm{O}$ artigo apresenta e discute a descrição e a análise que Tucídides realiza da peste ocorrida em Atenas no início da guerra do Peloponeso. O objetivo é buscar lições para os tempos de pandemia de Covid-19 no exame feito pelo historiador dos impactos morais e sociais das crises.

Palavras-chave: Tucídides; A peste em Atenas; Natureza humana; Pandemia

Abstract: The paper presents and discusses the description and analysis that Thucydides gave of the plague that broke out in Athens at the beginning of the Peloponnesian war. The aim is to seek lessons for the time of the Covid-19 pandemic from the historian's examination of the moral and social impacts of crises.

Keywords: Thucydides; the Plague of Athens; Human Nature; Pandemic

A disputa pela hegemonia na Grécia da segunda metade do século $\mathrm{V}$ a.C. foi a principal razão da guerra entre a liga comandada pelos atenienses e a coalização capitaneada pelos espartanos; guerra que se estendeu de 431 a 404, com um armistício de sete anos precariamente respeitado. O segundo ano do conflito foi particularmente penoso para Atenas. Densamente povoada com a presença de refugiados dos campos em decorrência da invasão dos peloponésios, a cidade viu irromper em 430, com uma segunda onda em 427, uma epidemia que dizimaria cerca de um terço de sua população ${ }^{1}$, afligindo todo o resto. Esse acontecimento tornou-se bem conhecido pela posteridade graças ao testemunho que dele Tucídides apresenta em sua história da guerra ${ }^{2}$. De fato, os capítulos 47-54 do livro II 3 da História da Guerra do Peloponeso constituem um dos textos mais célebres da literatura grega pela descrição dramática que oferece da peste e pela arguta análise de seus efeitos psicológicos, morais e sociais. Proponho-me aqui a reconstruir e destacar alguns detalhes desse texto a fim de buscar possíveis lições para nosso momento histórico. A leitora ou leitor

\footnotetext{
${ }^{1}$ A primeira onda durou dois anos, 430-429. Após o intervalo de uns dezoito meses, a segunda onda veio com força. Essa recrudescência é noticiada no livro III, capítulo 87, que fornece as cifras de baixas causadas pela doença no exército em quatro mil e quatrocentos hoplitas e trezentos soldados de cavalaria, números utilizados pelos especialistas para estimarem a quantidade total de mortos em mais que um quarto da população. Por essa mesma época, informa ainda Tucídides, outro desastre natural foram os abalos sísmicos ocorridos em Atenas, na Eubeia e na Beócia.

${ }^{2} \mathrm{O}$ relato de Tucídides é o único de quem presenciou (e no caso dele, se contaminou) a epidemia em Atenas. Entre os autores clássicos, somente Platão (Banquete, 201d) alude ao acontecimento. Lucrécio (De rerum natura, VI, 1138-1286) emula Tucídides fazendo como que uma tradução direta de seções da descrição da peste para o latim.

${ }^{3}$ A narrativa da peste segue-se imediatamente ao relato da oração fúnebre de Péricles. Existe presumivelmente uma moral por trás do arranjo e da justaposição destas passagens; enquanto a oração fúnebre glorifica a cidade civilizada de Atenas, os capítulos sobre a epidemia mostram como a civilização se esvai facilmente quando os tempos são difíceis. (WOODRUFF, Thucydides. On Justice, Power, and Human Nature, 46).
} 
certamente notará que cenas e situações enfrentadas pelos atenienses durante a epidemia do século $\mathrm{V}$ a.C. têm seus correspondentes na experiência que a humanidade hoje passa com a pandemia de Covid-19 vinte e cinco séculos depois.

Vejamos o relato. Tucídides introduz sua narrativa destacando a imprevisibilidade da peste e impotência humana diante dela ${ }^{4}$. O flagelo foi de tal modo impactante, incontrolável e acarretou tantas mortes que justificou seu registro histórico. De natureza desconhecida e altamente contagiosa, a moléstia era imbatível. Não se conhecia meios eficazes para enfrenta-la e conter a epidemia. Nem procedimentos médicos, nem outros cuidados habituais como dieta, sono e exercícios, nem súplicas por intervenção divina, nada funcionava. Os médicos não sabiam como tratar do doente, e expostos ao patógeno eles próprios eram os que mais rápido morriam. Rezar nos santuários e recorrer aos oráculos se mostravam ações completamente fúteis, e no fim as pessoas desistiram dessas práticas supersticiosas, como Tucídides as compreendia, oprimidas pela calamidade.

Quanto à origem, o historiador menciona a suposição de a pestilência ter começado na Etiópia, os confins do mundo para os gregos da época, e atravessando o Egito, a Líbia e territórios persas penetra em Atenas pelo Pireu, ou seja, chega de barco, como em vários casos de epidemia de que se tem notícia. Contudo, em nenhum outro lugar teria ocorrido na escala e com a agressividade da peste ateniense. Não faltaram alegações de tratar-se de um ato de bioterrorismo, acusando-se os peloponésios do gesto ímpio de "guerra total" com a suposta contaminação dos poços da zona portuária. Tucídides, porém, deixa a outros, seja médico seja leigo, o debate sobre a gênese e a causa da infecção. De sua parte, se concentrará em descrever como a doença evoluía e os sintomas a serem observados para que se possa reconhecê-la se voltar a acontecer. Com efeito, em vez de ocupar-se com teorias inverificáveis sobre a origem de um evento, Tucídides considerou mais produtivo descrevêlo com exatidão pois assim poderia estabelecer um padrão válido para o futuro, mesmo princípio que orientou a redação de sua História 5 .

Sem nomear a doença, o historiador passa a expor sua sintomatologia ${ }^{6}$. Por ter sido ele próprio uma vítima curada e testemunha ocular do sofrimento dos infectados foi capaz de expor com riqueza de detalhes o quadro da patologia e suas fases. Após um período de incubação, a infecção de súbito se manifestava. No primeiro estágio, o enfermo começava sentindo um calor na cabeça, apresentava em seguida vermelhidão e inflamação nos olhos, na faringe e na língua, passando a exalar um hálito fétido. Em uma segunda fase, vinham espirros e rouquidão; descendo ao peito a moléstia provocava tosse forte e chegando ao estômago causava vômitos de bile, mal-estar geral, ânsias de vômito e convulsões violentas mais ou menos duráveis. O corpo se tornava rubro e recoberto de pústulas e úlceras; e padecendo de uma febre interna terrível, o paciente não suportava roupas, desejava banhos frios e sofria de uma sede insaciável. Insônia e inquietação se somavam à agonia dos doentes, que podiam resistir conservando algum vigor até o sétimo ou oitavo dia, período fatal para a maioria dos casos. Se a pessoa sobrevivesse a este período crítico, em sua última

\footnotetext{
4 Embora ocupado com a busca de padrões que permitem certa previsibilidade da história, Tucídides não desconsiderou a obra do acaso ou dos acidentes que afetam as ações e a história humana. Mas não interpretou essas coisas como intervenção divina. A peste, vista como o acidente mais influente de toda a guerra, não é tratada por ele como castigo dos deuses. Simplesmente existem fatores externos, a fortuna (tyché), que escapam ao controle do ser humano, cujos planos, aliás, podem falhar por mais que inteligentemente concebidos. Sobre esse ponto, ver J. H. FINLEY, Thucydides, 313.

5 J. H. FINLEY, Thucydides, 69

6 Na ausência de evidências microbiológicas diretas, estudiosos e médicos modernos têm travado uma discussão interminável para identificar a doença com alguma conhecida. A varíola e a febre tifoide são as hipóteses mais apoiadas. Cf. PIRES, A peste de Atenas, mithistória em miniatura, 104 et seq.; SALLARES, The Ecology of the Ancient Greek World, 244- 62.
} 
fase, a doença descia aos intestinos, produzindo nele violenta ulceração e uma diarreia incontrolável que levava a maior parte dos doentes à morte pela astenia que causava. A infecção, portanto, descendo da cabeça tomava todo o corpo. A quem escapasse de seus piores efeitos, ela deixava ainda suas marcas ao chegar às extremidades atacando os órgãos genitais, os dedos das mãos e dos pés. Muitos sobreviveram perdendo essas partes do corpo, outros perderam a visão; houve casos de pacientes recuperados que perderam completamente a memória, não mais sabendo quem eles mesmos eram nem sendo capazes de reconhecer os amigos? ${ }^{7}$.

A precisão com que detalha os sintomas da peste servindo-se de um rico vocabulário técnico indica a familiaridade de Tucídides com os escritos de medicina da escola de Hipócrates, o pensamento médico do qual nosso autor sofreu influxo. A medicina que se estabelecia no século V se propunha a ser científica. Sua marca distintiva era a ideia de que ao se estudar uma enfermidade não se deveria levar em conta explicações religiosas ou puramente filosóficas; em vez disso, era preciso ater-se à observação dos sintomas e circunstâncias da doença para encontrar elementos comuns que permitissem compreender o fenômeno e agir, talvez, com alguma probabilidade de sucesso. Uma teoria fundamental dos tratados hipocráticos dizia que as doenças têm períodos de crise e que estudos clínicos minuciosos habilitam o médico a avaliar a provável gravidade desses períodos, não para os evitar - porque impossível - "mas auxiliar o máximo possível a capacidade de resistência do paciente" 8 .

De fato, é evidente a inspiração médica no modelo de precisão e na intenção prognóstica que Tucídides apresenta em sua obra. Descrevendo a epidemia, ele age como um médico. E é a mesma a justificativa que tem para avançar o diagnóstico da doença e para escrever sua obra histórica: ser de utilidade à posteridade. Efetivamente, quis deixar o registro sobre a peste a fim de que as pessoas no futuro fossem "capazes de aproveitar ao máximo, se ela se reproduzisse, o conhecimento prévio e não estivessem diante do desconhecido" 9 . Como parecia convencido de que o organismo social, como o individual, está sujeito a períodos de crises, escreve sua História para que tirem proveito os leitores interessados em como os seres humanos se comportam e nas coisas que se repetirão, dadas certas constantes da natureza humana.

Talvez a ausência do fabuloso nos fatos reportados fará parecê-los menos agradáveis à audiência; mas se quantos queiram ver claro os acontecimentos passados e aqueles que no futuro serão revelados, em conformidade com a natureza humana (kata to anthropinon), tais quais ou similares, julgarem útil minha narração, será suficiente. Foi composta como uma aquisição para sempre (ktema eis aei), não como uma peça de competição a se escutar no momento ${ }^{10}$.

Tucídides acredita que a história é útil e científica. É útil na medida em que as experiências passadas dão indicação das forças em ação no presente; e é científica porque aquelas forças estão contidas na natureza humana e, assim, podem ser estudadas e registradas como algo de permanente. Essa visão tucidideana reflete um postulado característico da mentalidade antropocêntrica grega em consolidação no século $\mathrm{V}$, a saber, que a verdade não se encontra na revelação divina nem nos aspectos meramente materiais da natureza, mas nos traços observáveis do caráter humano e nas tendências estáveis da sociedade. Em particular, a declaração de Tucídides expressa a concepção, defendida pelos

\footnotetext{
${ }^{7}$ Cf. II. 49, 2-8.

8 J. H. FINLEY, Thucydides, 69.

9 II. 48, 3. Traduzido a partir da versão francesa de ROMILLY.

${ }^{10}$ II. 22, 4. Traduzido a partir da versão italiana de DONINI.
} 
sofistas de sua época, de que "a conduta é previsível, que os homens de certa forma tendem a agir de determinada maneira, que certas condições sempre produzirão certos resultados; em suma, que a natureza humana está também sujeita a leis quase mecânicas. Que leis são estas pode ser difícil definir precisamente"11.

Note bem, o historiador não está afirmando que os acontecimentos de uma época irão se repetir exatamente no futuro e que, então, o leitor de sua História poderia predizer o porvir com exatidão, poderá, tomando consciência das forças que são permanentes na experiência humana descritas e analisadas pelo historiador, ter um indício forte do curso das coisas $^{12}$. Isso porque, pensava Tucídides, a natureza humana é uniforme, noção comunicada pela fórmula kata to anthropinon ${ }^{13}$, "em conformidade com a natureza humana". A ser assim, os eventos que resultam da deliberação humana, tais como guerras, crises políticas, respostas a epidemias e incontáveis outros de vários gêneros, por se realizarem segundo aquela natureza, são passíveis de previsão em seus aspectos típicos; e estes eventos, sendo o caráter humano o que é, sempre de alguma forma voltam a ocorrer, como as doenças.

Mas retornemos à narrativa da peste e vejamos a sequência do relato e a análise dos fatos feita por Tucídides. O caráter da moléstia de tão atípico era indescritível; e a violência de seu ataque era mais do que a natureza humana podia suportar (chalepoteros ê kata tên anthropeian physin ${ }^{14}$ ). Mais severa do que as doenças humanas normais, a infecção era mortífera mesmo para os animais que se alimentaram dos corpos insepultos. Durante a peste, as patologias comuns pareciam não mais afetar a população; e se qualquer outro mal se manifestasse, logo findava no da epidemia. Alguns morreram por falta de cuidados, outros apesar de muito bem assistidos. Não se descobriu um remédio que pudesse ser administrado com segurança e eficácia, pois o que beneficiava um paciente resultava nocivo a outro. Tampouco havia alguém que por sua constituição física fosse imune à moléstia, indiscriminadamente ela atingia os fortes e os fracos, não escapando nem os indivíduos que viviam nas melhores dietas. Mas, Tucídides destaca, era no espírito que a peste mostrava seu aspecto mais nefasto.

Porém, a coisa mais terrível de todas era o desânimo no qual as pessoas caiam quando notavam que tinham sido pegas pela praga; pois elas imediatamente se desesperavam e, dando-se por vencidas, perdiam o poder de resistência. Terrível também era o fato de morrerem como rebanhos ao se contagiarem devido ao cuidado que uns prestavam aos outros; de fato, essa era a causa que provocava a maior mortandade ${ }^{15}$.

A praga causava devastação nas estruturas emocionais, morais e sociais, abalando as relações humanas. Sua fácil transmissão criava dilemas e tornava a solidariedade uma virtude arriscada. Havia gente que, por medo, se isolava em suas casas e acabavam morrendo no abandono, "e muitas casas ficaram vazias por falta de alguém disposto a oferecer seus cuidados"16. Em contraste, outras pessoas perderam a vida depois de se

\footnotetext{
${ }^{11}$ J. H. FINLEY, Thucydides, 109.

${ }^{12}$ J. H. FINLEY, Thucydides, 292. Finley sustenta que a História de Tucídides é particularmente destinada aos políticos. Escreve o comentador: "Now to Thucydides the supreme requisite of a politician is his $\pi \rho$ ó$v \omega \sigma \mathrm{l} \varsigma-$ his ability to foresee - and the History itself is, in essence, a manual for future statesmen, instructing them in the outcome of conditions destined to be repeated." (50).

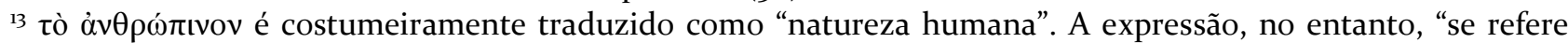
seja à natureza do homem, seja a seu comportamento, seja a tudo que tem a ver com o homem enquanto influi sobre ele e o impele a comportar-se de um certo modo" (DONINI, Introduzione In: Le Storie di Tucidide, 27).

${ }^{14}$ II. 5O, 1.

15 II. 51, 4. Traduzido a partir da versão espanhola de ESBARRANCH.

${ }^{16}$ II. 51, 5. Traduzido a partir da versão espanhola de ESBARRANCH.
} 
contagiarem nas visitas aos doentes; era o caso sobretudo daquelas que, movidas por seu senso de dever, descuravam-se de si mesmas e entravam nas casas de amigos quando já os próprios familiares, esmagados pelo peso da calamidade, sequer tinham forças para chorar seus mortos. Mas a maior e talvez mais sincera empatia pelos moribundos vinha dos indivíduos que tinham se curado. Estes adquiriam defesas que tornavam a reinfecção rara e não fatal. Parabenizados pelos outros e eufóricos por terem sobrevivido, alguns nutriram a frívola e infundada crença de estarem imunes a qualquer enfermidade.

Tucídides em seguida chama a atenção para as circunstâncias que agravavam a epidemia: a aglomeração de camponeses pobres, dentro dos muros de Atenas por conta da estratégia defensiva de Péricles, vivendo nas mais insalubres condições em barracas sufocantes na estação quente. Este grupo foi o que mais sofreu com a peste, nele a morte grassava sem controle. $\mathrm{O}$ historiador prossegue com um relato lúgubre das cenas pavorosas que testemunhou:

Os corpos dos moribundos se amontoavam e pessoas semimortas rolavam nas ruas e perto de todas as fontes em sua ânsia por água. Os templos nos quais se haviam alojado estavam repletos dos cadáveres daqueles que morriam dentro deles, pois a desgraça que os atingia era tão avassaladora que as pessoas, não sabendo o que as esperava, tornavam-se indiferentes a todas as leis, quer sagradas, quer profanas. Os costumes até então observados em relação aos funerais passaram a ser ignorados na confusão reinante, e cada um enterrava os seus mortos como podia. Muitos recorreram a modos escabrosos de sepultamento, porque já haviam morrido tantos membros de suas famílias que já não dispunham de material funerário adequado. Valendo-se das piras dos outros, algumas pessoas, antecipando-se às que as haviam preparado, jogavam nelas seus próprios mortos e lhes ateavam fogo; outros lançavam os cadáveres que carregavam em alguma já acesa e iam embora ${ }^{17}$.

O desespero provocado pelo risco de morte iminente levou ao abandono das regras morais e à violação das leis civis e divinas mais sagradas e respeitadas em Atenas. Morrer, ou nascer, no interior de um templo era um enorme sacrilégio; e um opróbrio extremo para uma família não providenciar a seus falecidos um sepultamento digno realizando as exéquias que os costumes exigiam. A situação era, portanto, de excepcionalidade e anomia. Para culminar, o destino final dos restos mortais se somava à consternação como um problema tanto sanitário quanto moral, em uma cultura para qual os ritos funerários era uma lei da tradição e uma lei perene dos deuses ${ }^{18}$.

O clímax da narrativa da peste é alcançado no capítulo 53; as considerações prévias foram uma longa preparação para este momento. Talvez mais que outros, esse trecho merece ser citado extensamente:

De um modo geral a peste introduziu na cidade pela primeira vez a anarquia (anomia) total. Ousava-se com a maior naturalidade e abertamente aquilo que antes só se fazia ocultamente, vendo-se quão rapidamente mudava a sorte, tanto a dos homens ricos subitamente mortos quanto a daqueles que antes nada tinham e num momento se tornavam donos dos bens alheios. Todos resolveram gozar o mais depressa possível todos os prazeres que a existência ainda pudesse proporcionar, e assim satisfaziam os seus caprichos, vendo que suas vidas e riquezas eram efêmeras. Ninguém queria lutar pelo que antes considerava honroso, pois todos duvidavam de que viveriam o bastante para obtê-lo; o prazer do momento, como tudo que levasse a ele, tornou-se digno e conveniente; o temor dos deuses e as leis dos homens já não detinham ninguém, pois vendo que todos estavam morrendo da mesma forma, as pessoas passaram a pensar que impiedade e piedade eram a mesma coisa; além disto, ninguém esperava estar vivo para ser chamado a prestar contas e responder por seus

${ }^{17}$ II. 52, 3-4. Trad. CURY.

${ }^{18}$ Cf. SÓFOCLES, Antígona, 450-455. 
atos; ao contrário, todos acreditavam que o castigo já decretado contra cada um deles e pendente sobre suas cabeças, era pesado demais, e que seria justo, portanto, gozar os prazeres da vida antes de sua consumação ${ }^{19}$.

O excerto evidencia o interesse de Tucídides em observar os impactos morais que as situações-limite geram para as pessoas e como estas situações revelam a natureza humana. O mesmo interesse se explicita na seção sobre as consequências morais e políticas da guerra civil (stasis) na Córcira, passagem que tem um claro paralelo com a supracitada. Em 427, eclodiu na distante ilha dos corcireus uma guerra civil entre a facção democrática e a oligárquica, apoiada cada uma por uma das potências adversárias na guerra: os democratas por Atenas, os oligarcas por Esparta. A revolta instaurou uma atmosfera de ódio e intolerância, levando a uma situação política marcada pela desconfiança, traições, intrigas, perseguições, assassinatos e massacres (III. 69 - 85). Tendo exposto a sequência dos eventos e os atos deploráveis que, com os ânimos acirrados, as pessoas praticaram durante a sedição, fenômeno que se disseminou por várias cidades, Tucídides faz o seguinte balanço, extraindo (como característico de sua obra) categorias gerais de casos concretos $^{20}$.

Dessa forma as revoluções trouxeram para as cidades numerosas e terríveis calamidades, como tem acontecido e continuará a acontecer enquanto a natureza humana for a mesma; elas, porém, podem ser mais ou menos violentas e diferentes em suas manifestações, de acordo com as várias circunstâncias presentes em cada caso. Na paz e prosperidade as cidades e os indivíduos têm melhores sentimentos, porque não são forçados a enfrentar dificuldades extremas; a guerra (ho polemos), ao contrário, que priva os homens da satisfação até de suas necessidades cotidianas, é uma mestra violenta (biaios didaskalos) e desperta na maioria das pessoas paixões em consonância com as circunstâncias do momento. Assim as cidades começam a ser abaladas pelas revoluções, e as que são atingidas por estas mais tarde, conhecendo os acontecimentos anteriores, chegam a extravagâncias ainda maiores em iniciativas de uma engenhosidade rara e em represálias nunca antes imaginadas ${ }^{21}$.

Não são apenas as constantes fisiológicas e psicológicas do caráter humano que explicam a conduta dos indivíduos, mas também as suas circunstâncias; de modo que se pode afirmar, como J. H. Finley lembrando Simônides, que o homem é majoritariamente uma criatura das circunstâncias: "Ele é bom se sua sorte for boa e mau se ela for má"22. A guerra, como as revoluções e os desastres naturais, provocando uma violenta perturbação da ordem estabelecida, ensina a maioria das pessoas a conformarem suas paixões à ferocidade da situação; como consequência, instaura-se na cidade a anomia - ilegalidade, anarquia, desordem.

Junto com a degradação moral, a stasis na Córcira ocasionou uma subversão da linguagem: os homens mudaram os sentidos habituais das palavras de acordo com as interpretações que queriam dar a seus atos. Nessa novilíngua (para usar o termo de George Orwell), o que antes era indecoroso e repreensível se torna apreciável e estimulado, e viceversa.

A audácia irracional passa a ser considerada lealdade corajosa em relação ao partido; a hesitação prudente se torna covardia dissimulada; a moderação passa a ser uma máscara para a fraqueza covarde, e agir inteligentemente equivale à inércia total. Os impulsos precipitados são vistos como uma virtude viril, mas a prudência no

\footnotetext{
19 II. 53, 1-4. Trad. CURY.

20 Sobre a prática de Tucídides de realizar reflexões gerais sobre fatos particulares, ver ROMILLY, La construzione della verità in Tucidide, 35-64; PRADO, O lógos de Tucídides sobre a guerra, 13 et passim.

${ }^{21}$ III. 82, 2-3. Trad. CURY.

${ }^{22}$ J. H. FINLEY, Thucydides, 42.
} 
deliberar é um pretexto para a omissão. O homem irascível sempre merece confiança, e seu oposto se torna suspeito. O conspirador bem-sucedido é inteligente, e ainda mais aquele que o descobre, mas quem não aprova esses procedimentos é tido como traidor do partido e um covarde diante dos adversários. Em suma, ser o primeiro nessa corrida para o mal e compelir a entrar nela quem não queria é motivo de elogios ${ }^{23}$.

A sanha na política não provoca apenas uma transmutação de todos os valores, ela põe em xeque a própria manutenção do "pacto social" ao permitir que o fanatismo, o fisiologismo e o revanchismo prevaleçam sobre a moderação, a honestidade e o bom senso. Poderíamos dizer que, para Tucídides, o adoecimento do corpo social que compromete a própria sobrevivência da polis se manifesta quando "de um modo geral os homens passam a achar melhor ser chamados canalhas astuciosos que tolos honestos, envergonhando-se no segundo caso e orgulhando-se no primeiro" 24.

De todos os males que aconteceram na Córcira, a guerra é a razão evidente; entretanto a verdadeira causa ${ }^{25}$ é algo que o historiador indica como presente na natureza humana: "o amor ao poder perseguido por cobiça e ambição; destes dois sentimentos provém, quando as rivalidades se instauram, o ardor apaixonado" ${ }^{26}$. A cidade passa pelas piores crises quando seus governantes, servindo-se de palavras especiosas, exercem o poder somente no interesse próprio, em vista de obter vantagens pessoais e para seu grupo. Esse tipo de comportamento os gregos descreviam com o termo pleonexia - ambição, locupletamento.

Apontando a real causa da stasis, Tucídides parece explicitar sua própria visão da natureza humana notoriamente pessimista. Os seres humanos são, por natureza, pleonéticos, movidos somente pelo interesse próprio e irascíveis. Aqui, como em outras partes de sua obra, o historiador repercute ideias correntes acerca do caráter humano a que os sofistas davam expressão. Com efeito, nos círculos sofísticos uma questão muito discutida concernia ao que deveria ser tomado como a verdadeira fonte dos valores e do padrão de conduta dos indivíduos, se a physis (entendida como natureza humana) ou se o nomos (lei, costume, norma, convenção, moralidade). Sabemos de uma defesa da physis a partir dos argumentos dos sofistas Trasímaco e Cálicles que figuram como personagens platônicos, respectivamente, na República I e no Górgias. A ideia que ambos tinham em comum era que, contra a fingida moralidade popular do autocontrole e igualdade de direitos, existem leis naturais que devem ser atendidas. Aqueles com qualidades superiores e inteligência têm o direito de dominar sobre os que lhes são inferiores por natureza e devem usá-los para promover seus próprios interesses.

Dessa forma de pensar - evidentemente associada ao imperialismo ateniense - uma das mais famosas ilustrações em Tucídides é o diálogo mélio (V. 85-111). Em 416 a pequena ilha de Melos teve sua população masculina adulta executada e a restante escravizada ${ }^{27}$ porque se recusaram a aliar-se à confederação ateniense. Tucídides representa o que teria sido o debate entre os enviados de Atenas e o conselho dos mélios. Os atenienses começam com a advertência de excluir da discussão a retórica dos valores convencionais, já que ambas as partes sabem bem que, pelos raciocínios humanos, a justiça depende da igualdade de

\footnotetext{
23 III. 82, 4-5. Trad. CURY.

24 III. 82. 7. Trad. CURY.

${ }^{25}$ Em I. 23, 6, Tucídides traça a distinção entre prophasis (causa) e aitia (razão) da guerra; aquela se refere à agressão que desencadeou o conflito, esta as motivações não declaradas que levou a guerra: a expansão do poder de Atenas na Hélade (I. 23, 6; 88; 118, 2).

${ }^{26}$ III. 82, 8. Traduzido a partir da versão francesa de ROMILLY.

${ }^{27}$ Atrocidade de que foi poupada a cidade de Mitilene, depois de contida sua revolta contra Atenas (III. 36-50), e que os atenienses cometeram contra Cicione (V. 32, 1).
} 
poder, e que o mais forte faz o que pode e o mais fraco se submete. Porque impedidos de falar em justiça, os mélios, então, aceitam os termos dos atenienses e apelam ao conveniente ou vantajoso (to xypheron), afirmando ser útil tratar com justiça convencional aqueles que estão em perigo, o que deve estar no interesse dos próprios atenienses, pois poderão um dia necessitar de tratamento justo. A arrogância dos atenienses fê-los desprezar essa hipótese. E ao argumento religioso de que seus agressores, por estarem atentando contra a justiça, corriam o risco de perder a proteção divina, os mélios ouvem a seguinte resposta:

Dos deuses nós supomos e dos homens sabemos que, por uma imposição de sua própria natureza, sempre que podem eles mandam. Em nosso caso, portanto, não impusemos esta lei nem fomos os primeiros a aplicar os seus preceitos; encontramola vigente e ela vigorará para sempre depois de nós; pomo-la em prática, então, convencidos de que vós e os outros, se detentores da mesma força nossa, agiríeis da mesma forma ${ }^{28}$.

É discutível que Tucídides tenha sido fautor de um tal realismo amoral ${ }^{29}$ e que sua falta de condenação ao ato signifique que tenha aprovado a crueldade impingida aos mélios. Se é verdade que não nutria ilusões quanto a uma bondade inata no ser humano, o historiador parecia defender a autoridade do nomos para conter os abusos que, por natureza, as pessoas tendem a cometer, se puderem. Tanto quanto possível reconstitui-la, a posição tucidideana é similar a advogada por Protágoras, como conhecida a partir do diálogo homônimo de Platão, de que a virtude do homem, entenda-se a prática eficaz dos valores e regras instituídas pela comunidade, é aquilo de que depende a sociedade para subsistir. Desprovidos do senso de pudor (aidos) e de justiça (dike) e da virtude política que estes baseiam, os indivíduos são incapazes da vida em sociedade. A moralidade, que se aprende desde cedo nas relações mútuas na cidade, é o que aperfeiçoa o ser humano e mantém a comunidade coesa e próspera.

Que Tucídides acreditava ser o nomos condição necessária para refrear os impulsos da natureza e manter a ordem e a estabilidade política, temos uma eloquente evidência em suas considerações finais sobre a stasis na Córcira $^{30}$. Na reinante confusão no período de guerra civil, a natureza humana apresentou-se em sua forma pura e tal como ela realmente é. Sempre pronta a violar a justiça e a lei, mostrou-se escrava da cólera, senhora da justiça e inimiga do que há de superior. Não fosse assim, e se a inveja não tivesse exercido seu poder pernicioso, os cidadãos não teriam preferido a vingança às regras sagradas, nem o ganho no

${ }^{28}$ V. 105, 1-2. Trad. CURY.

29 THOMAS destaca que "The presence of an idea or technique in Thucydides does not by itself imply that he accepts it, rather than attributing it to one of his speakers" (Thucydides' Intellectual Milieu and the Plague, 91). Todavia, reunindo-se evidências esparsas na História, parece correta a síntese do pensamento de Tucídides oferecida por M. I. FINLEY: "He [Tucídides] had a pessimistic view of human nature and therefore of politics. Some individuals and some communities, by their moral qualities, are entitled to positions of leadership and power. But power is dangerous and corrupting, and in the wrong hands it quickly leads to imoral behaviour, and then to civil strife, unjust war and destruction." (Introduction In: Thucydides - History of the Peloponnesian War, 31). De fato, não devemos esquecer que Tucídides foi um general que combateu na guerra, que depois no exílio permaneceu um patriota e admirador de Péricles; assim, não admira ele não fazer objeção ao exercício de poder de Atenas, ainda que na construção de seu império os atenienses possam ser vistos como praticando o egoísmo em larga escala. Por outro lado, Tucídides defendeu que dentro de cada cidade a lei e a moralidade restringissem o egoísmo desinibido dos indivíduos. Ambas atitudes parecem gerar um dilema, como aponta RHODES: ao mesmo tempo que o historiador parece ter considerado uma grande vantagem para Atenas, no nível da atividade de estado, desprezar as restrições convencionais para agir de acordo com a natureza, no nível da atividade individual dentro da cidade, considerou melhor para cada pessoa que as convenções prevaleçam. (The Athenian Impire, 36).

$3^{0}$ Trata-se do capítulo 84 do livro III, que é considerado uma interpolação posterior, mas que pela coerência parece legitimar-se como tucidideano. Sobre isso, ver REEVE, Thucydides on Human Nature. 
lugar de evitar a injustiça. "Quando querem se vingar de outros, os homens primeiro se põem a destruir as leis geralmente aceitas a propósito do caso, ainda que seja só por causa delas que uma pessoa em dificuldade pode esperar ser salva, e qualquer um pode ficar em perigo um dia e necessitar de tais leis"31. Em outros termos, para Tucídides, em si mesma a natureza humana é impulsiva e impetuosa, deixada solta pode conduzir os indivíduos a planos e ações desagregadoras e ruinosas para o conjunto da sociedade. Mas ela não é absolutamente indomável. A justiça e as leis são também do interesse humano, portanto, úteis. Servem para que os humanos se protejam de si mesmos e possam mais segura e comodamente sobreviver.

Voltemos, para finalizar, à narrativa da epidemia, mais precisamente à espécie de epílogo com que Tucídides conclui seu relato. A desgraça vivida por Atenas, vendo seu povo a morrer dentro das muralhas e suas terras sendo devastadas fora, trouxe à lembrança do povo um verso oracular: "Virá um dia a guerra dória, e com ela a peste". À época, discutiu-se se a palavra no verso era peste (loimos) ou fome (limos). Dada a tendência das pessoas a se adaptarem às situações que se apresentam e a tomarem a situação corrente como único padrão, prevaleceu a opinião de que era loimos; a memória dos indivíduos, afinal, reflete seus sofrimentos. Outro oráculo recordado, continua Tucídides, foi o recebido pelos espartanos a sua consulta a Apolo - o deus da medicina que curava as doenças, mas que também as enviava e produzia pestes ${ }^{32}-$ que responde prometendo auxílio aos peloponésios ${ }^{33}$. Como a peste surtiu logo após a primeira invasão, massacrou Atenas, mas não se estendeu ao Peloponeso, muitos acreditaram no cumprimento do vaticínio. Tucídides não questiona, mas também não endossa, essa crença; simplesmente sugere que as pessoas fazem as profecias se ajustarem as suas circunstâncias presentes ${ }^{34}$. Mas é evidente que para nosso autor são as ações humanas e não a intervenção divina o que explica a história; portanto, para ele, os prognósticos fundamentados na observação tomam o lugar de previsões baseadas na religião.

Atenas sobreviveu à peste, e sem que o flagelo tenha causado alguma mudança digna de nota nas estruturas de sua sociedade, política e economia. Ao contrário, se em um primeiro momento houve movimentação para pôr fim à guerra, os atenienses decidiram permanecer no conflito e assim fizeram recrudescendo sua política externa imperialista, prepotente e agressiva; política que, conduzida por demagogos desqualificados (como Tucídides avaliava os sucessores de Péricles tomando Cleon por modelo), levou Atenas à insensatez e desgraça.

Para concluir, que lições retirar de Tucídides para o momento histórico que vivemos no Brasil, assolados por uma calamidade sanitária, gerenciada pelo governo federal com a mais brutal necropolítica, e pesteados por profundas crises política e econômica que impõem retrocessos e perdas de avanços civilizatórios a duras penas conquistados? Penso que há muitas lições, mas a principal delas talvez seja o destaque ao papel revelador das crises e a necessidade de diagnóstico preciso do processo histórico. A pandemia e os problemas que gerou ou agravou em nosso país têm evidenciado os resultados de nossa aceitação, enquanto sociedade, da cruel desigualdade social, gestada pela secular história de

\footnotetext{
${ }^{31}$ III. 84, 3. Traduzido a partir da versão inglesa de WOODRUFF.

${ }^{32}$ Assim apresentado por Homero, Ilíada Canto I.

33 Cf. I. 118, 3.

34 MARINATOS, Thucydides and Oracles, 139. Marinatos desafia a communis opinio segundo a qual Tucídides foi cético a respeito dos oráculos tratando-os como uma forma de superstição. O comentador examina e reinterpreta um conjunto de passagens da História advogando que o autor aceitou os oráculos com análoga atitude piedosa de seus contemporâneos Heródoto e Sófocles, e que ele teve de fato "a consistent interest in oracular puzzles and their correct interpretation”. (138).
} 
abusos e extermínio de povos e de pessoas mais vulneráveis; têm mostrado as consequências da indiferença ao racismo estrutural, à discriminação de gênero, à homofobia, à violação de direitos básicos, à subtração de oportunidade para um imenso contingente da população; têm deixado claros os efeitos da complacência do país à ganância desenfreada dos mais ricos e à exploração impiedosa dos mais pobres na mais inaceitável inversão de valores que coloca a vida em função da economia. Além da tolerância a tudo isso, a tão comum indulgência aos perpetradores de crimes de lesa-pátria e lesa-humanidade, a leniência com o desvirtuamento das instituições da república, com ilegalidades, com a "justiça” seletiva e a insegurança jurídica, bem como o hábito de naturalizar arbítrios, absurdos e barbárie jogam contra a consolidação de nossa frágil democracia e contra a construção de uma sociedade mais justa e inclusiva. Assim, para reduzirmos nossa suscetibilidade a crises agudas que se tornam crônicas, é necessário que façamos a crítica a nossa história, reconhecendo nela os padrões, corrigindo as constantes desfavoráveis e promovendo a consciência política, pois se persistimos com os mesmos comportamentos não podemos esperar resultados diferentes, como nos ensina a obra intemporal de Tucídides.

\section{Referências}

DONINI, Guido. Le Storie di Tucidide. Volumes I e II. Torino: Editrice Torinese, 1982.

DONINI, Guido. Introduzione. In: Le Storie di Tucidide. Volume I. Torino: Editrice Torinese, 1982.

DRAEGER, Andréa Coelho Farias. Para além do lógos: a peste de Atenas na obra de Tucídides. Rio de Janeiro: UFRJ/FL, 2004. (Dissertação de Mestrado).

FINLEY, John H. Thucydides. Cambridge: Harvard University Press, 1942.

FINLEY. M. I. Introduction. In: History of the Peloponnesian War. Trad. Rex Warner. London: Penguin, 1954.

GOMME, A. W. A Historical Commentary on Thucydides. Volume II, Books II-III. Oxford: Clarendon Press, 1956.

HORNBLOWER, Simon. A Commentary on Thucydides. Volume I, Books I-III. Oxford: Clarendon Press, 1991.

KERFERD, G. B. O movimento sofista. Trad. Margarida Oliva. São Paulo: Loyola, 2003.

LLOYD, G. E. R. In the Grip of Disease. Studies in the Greek Imagination. Oxford: Oxford University Press, 2003.

MARINATOS, Nanno. Thucydides and Oracles. The Journal of Hellenic Studies, v. 101, 1981, pp. 138-140.

MBEMBE, Achille. Necropolítica. Biopoder, soberania, estado de exceção, política da morte. Trad. Renata Santini. S/1.: n-1 edições, 2018.

PIRES, Francisco Murari. A peste de Atenas, mi historia em miniatura: o daímon e a heroicidade do historiador. Letras Clássicas, n. 12, 2008, pp. 99-116.

PRADO, Anna Lia A de A. O lógos de Tucídides sobre a guerra. classica - revista brasileira de estudos clássicos, v. 2, n. 1, 1989.

REEVE, C. D. C. Thucydides on Human Nature. Political Theory, v. 27, n. 4, 1999, pp. 435446. 
RHODES, J. P. The Athenian Empire. Oxford: Oxford University Press, 1993.

ROMILlY, Jacqueline de. Thucydide. La Guerre du Péloponnèse, Livre I. (Texte établi et traduit). Paris: Les Belles Lettres, 1953.

ROMILLY, Jacqueline de. Thucydide. La Guerre du Péloponnèse, Livre II. (Texte établi et traduit). 3 ed., Paris: Les Belles Lettres, 1973.

ROMILLY, Jacqueline de; WEIL, Raymond. Thucydide. La Guerre du Péloponnèse, Livre III. (Texte établi et traduit). 3 ed., Paris: Les Belles Lettres, 1969.

ROMILLY, Jacqueline de. La construzione della verità in Tucidide. Trad. M. L. Ferrari. Firenze: La Nuova Italia Editrice: 1995.

SALLARES, R. The Ecology of the Ancient Greek World. Ithaca: Cornell University Press, 1991. SÓFOCLES. Antígona. Trad. D. Schüler. Porto Alegre: L\&PM, 1999.

STAHL, H.-P. Thucydides - Man's Place in History. Swansea: The Classical Press of Wales, 2003.

TUCÍDIDES. História da Guerra do Peloponeso. Trad. Mário da Gama Cury. Brasília: UnB, 1987.

TUCÍDIDES. Historia de la Guerra del Peloponeso. Libros I-II. Trad. J. J. Torrés Esbarranch. Madrid: Gredos, 1990.

THUCYDIDES. History of the Peloponnesian War. Trad. Rex Warner. London: Penguin, 1954. THOMAS, Rosalind. Thucydides' Intellectual Milieu and the Plague. In: RENGAKOS, A.; TSAKMAKIS, A. (eds.). Brill's Companion to Thucydides. Leiden/Boston: Brill, 2006, pp. 87108.

WOODRUFF, Paul. Thucydides. On Justice, Power, and Human Nature. Indianapolis/Cambridge: Hacket, 1993. 